\title{
Myopathies in the Intensive Care Unit
}

\author{
Douglas Zochodne
}

\begin{abstract}
Myopathies that occur in the intensive care unit can be divided into preexisting myopathies or newly acquired myopathies that develop in the intensive care unit. Myotonic dystrophy is an example of a preexisting myopathy that may render patients susceptible to acute respiratory failure following surgical procedures and anaesthesia. A group of myopathies that develop within the intensive care unit have been labelled acute necrotizing myopathy of intensive care, thick filament myopathy and acute steroid myopathy. Corticosteroids and nondepolarizing muscle blocking agents may play a role in their development.
\end{abstract}

RÉSUMÉ: Myopathies à l'unité de soins intensifs. Les myopathies rencontrées à l'unité de soins intensifs sont soit préexistantes, soit acquises au cours du séjour à l'unité de soins intensifs. La dystrophie myotonique est un exemple d'une myopathie préexistante qui peut précipiter une insuffisance respiratoire aiguë suite à une chirurgie et à une anesthésie. Un groupe de myopathies survenant à l'unité de soins intensifs pourraient être interreliées et ont été identifées comme la myopathie nécrosante aiguë des soins intensifs, la myopathie à filaments larges et la myopathie aiguë aux stéroïdes. Les corticostérö̈des et les agents curarisants non dépolarisants pourraient jouer un rôle dans leur développement.

Can. J. Neurol. Sci. 1998; 25: S40-S42

\section{Myopathies in Critical Illness}

This is a very brief review of both newly acquired and preexisting myopathies that may develop in adults patients admitted to the intensive care unit (Table). The reader is referred to more detailed reviews on this topic. ${ }^{1}$

\section{Table: Myopathies in the Intensive Care Unit}

\section{Preexisting disorders:}

- Inflammatory myopathies ${ }^{22,23}$

- Alcoholic rhabdomyolysis ${ }^{15}$

- Myotonic dystrophy ${ }^{2-5}$

- Periodic paralyses

- Malignant hyperthermia ${ }^{21}$

- Acquired hypokolemic weakness ${ }^{15}$

- Acid maltase deficiency ${ }^{6-14}$

- Mitochondrial myopathies ${ }^{17}$

- Limb girdle muscular dystrophy ${ }^{18}$

- HIV related myopathy 19

- Trichinosis 25

- Sarcoid myopathy ${ }^{20}$

- Carnitine palmitoyl transferase deficiency ${ }^{16}$

- Hypophosphatemic myopathy ${ }^{15.24}$

Myopathies that develop in the intensive care unit:

- Necrotizing myopathy associated with non-depolarizing muscle blocking agents ${ }^{26,29}$

- Acute steroid myopathy ${ }^{27,28}$

- Septic myopathy ${ }^{39}$

- Myopathy of critical illness ${ }^{39}$

- Hypophosphatemia ${ }^{15,24}$

\section{General Features}

It is uncommon, but not rare to make the diagnosis of a more longstanding myopathy in an adult for the first time in the intensive care unit. Other myopathies may be iatrogenic. Patients in the intensive care unit with myopathies may have varying degrees of bulbar involvement including ptosis and neck flexor weakness. Reflexes are lost in some patients but sensation is preserved. Electrophysiological features include reduced $M$ potential amplitudes, normal motor conduction velocity and preserved sensory conduction. Needle electromyography may disclose abnormal spontaneous activity such as fibrillation potentials, positive sharp waves and myotonic discharges. Fibrillations are less numerous than those recorded after denervation and are probably associated with muscle fiber necrosis. If the patient can recruit motor units, they may be reduced in amplitude and duration.

\section{Patients With Preexisting Myopathies}

Patients with myotonic dystrophy have an important but avoidable susceptibility to acute respiratory failure following surgical procedures requiring the use of anaesthesia, opioids and sedatives. ${ }^{2}$ The cause of this susceptibility is uncertain but may be due to an abnormality of central respiratory drive linked to hypersomnia. ${ }^{3-5}$ There is no evidence that specific treatment for myotonia facilitates more rapid weaning. Acid maltase deficiency, an autosomal recessive deficiency of glycogen degrading

From the Department of Clinical Neurosciences, University of Calgary, Calgary. Reprint requests to: D.W. Zochodne, University of Calgary. Department of Clinical Neurosciences, Room 182A, 3330 Hospital Drive N.W., Calgary, Alberta, Canada T2N 4NI 
alpha-1, 4-glucosidase may be associated with a myopathy and respiratory insufficiency in adults. ${ }^{6-14}$ Myotonia may be a prominent feature on EMG testing. Muscle biopsy may identify accumulation of PAS positive glycogen but specific enzyme assays are required for the diagnosis. Ventilatory support is important in these patients because spontaneous recovery may occur, even after prolonged ventilator dependence.

There are a variety of other myopathies that rarely might render enough weakness to place the patient in an intensive care unit. These might include: a rhabdomyolytic syndrome from hypokalemia, ${ }^{15}$ myopathy associated with carnitine palmitoyl transferase deficiency, ${ }^{16}$ certain mitochondrial myopathies, ${ }^{17}$ limb girdle muscle dystrophy, ${ }^{18}$ HIV myopathy ${ }^{19}$ and sarcoid myopathy involving the diaphragm. ${ }^{20}$ Patients with malignant hyperthermia may be admitted to an intensive care unit during crisis. ${ }^{21}$ There are reports of patients with inflammatory myopathies requiring admission to the unit. ${ }^{22,23}$ Finally, one might include acute alcoholic rhabdomyolysis ${ }^{15}$ myopathy from hypophosphatemia ${ }^{15,24}$ and myositis from trichinosis. ${ }^{25}$

\section{Myopathies That Develop in the Intensive Care Unit}

The most important of these occurs in patients that have been exposed to high doses of glucocorticoids and infusions of nondepolarizing muscle blocking agents to treat acute pulmonary disorders, such as asthma. They have been labelled as an acute necrotizing myopathy of intensive care, floppy person syndrome, thick filament myopathy, acute quadriplegic myopathy, or acute steroid myopathy. ${ }^{26-29}$ There may be a severe flaccid arreflexic quadriplegia, sometimes with complete ophthalmoplegia. Electrophysiological studies may identify a persistent neuromuscular transmission deficit ${ }^{26,30}$ in instances where vecuronium has been given. This is from the accumulation, and activity of a metabolite of vecuronium, 3 desacetylvecuronium. ${ }^{30}$ The presence of myopathy is indicated by only partial recovery of the patient despite later (after 1 week) complete repair of the neuromuscular transmission deficit. At this time there may be persistently low amplitude motor $\mathbf{M}$ potentials with preserved motor conduction velocity and relatively intact sensory conduction. Needle electromyography may detect mild to moderate abnormal spontaneous activity consisting of fibrillation potentials and positive sharp waves. If the patient is able to recruit motor unit potentials, they may be reduced in amplitude and highly polyphasic suggesting a primary myopathy. Serum CK levels may rise very high, especially with vecuronium because of rhabdomyolysis rendering myoglobinuria, and acute renal failure. Muscle biopsy may identify milder changes such as fiber atrophy and myosin filament loss, or severe muscle fiber necrosis. ${ }^{29.31}$ Necrosis may be panfascicular with fibers exhibiting vacuolation or hypereosinophilia. ${ }^{29}$ If the patient is appropriately supported complete recovery can occur. Critical illness neuropathy may also occur in these patients. ${ }^{26}$ Some instances, where the patient has been treated with high dose steroid alone for asthma, are probably examples of steroid myopathy alone. These patients may only have thick filament loss and Type II fiber atrophy. In other cases, where patients exposed to vecuronium develop rhabdomyolysis with less or no exposure to steroid, there may be a unique toxic action of vecuronium on muscle. Whether additional factors, such as age or preexisting nutrition influence the development of these myopathies is uncertain.
Patients with sepsis that have not been exposed to steroid and nondepolarizing muscle blocking agents can develop myofiber necrosis sometimes linked to specific organisms, such as Escherichia coli septicaemia, ${ }^{32}$ Leptospirosis, ${ }^{33,34}$ Legionella disease $^{35}$ and staphylococcus aureus. ${ }^{36-38}$ Muscle biopsy may, on occasion identify multiple microabscesses. In previous work, we have suggested that sepsis may have a direct action on muscle resulting in a loss of phosphocreatine energy stores with resulting contractile failure. ${ }^{39}$ Sepsis itself may also be associated with catabolic muscle proteolysis, but it is controversial whether this alone can account for a myopathy involving respiratory muscles. CK and electrophysiological studies are normal in catabolic myopathy.

\section{ACKNOWLEDGEMENTS}

Brenda Boake provided expert secretarial assistance. DWZ is a medical scholar of the Alberta Heritage Foundation for Medical Research.

\section{REFERENCES}

1. Zochodne DW, Bolton CF. Neuromuscular disorders in Critical Illness. In: Bolton CF, Young GB, eds. Ballier's Clinical Neurology. Critical Care, 1996; 5: 645-671.

2. Kohn NN, Faires JS, Rodman T. Unusual manifestation due to involvement of involuntary muscle in dystrophica myotonica. $\mathrm{N}$ Engl J Med 1964; 271: 1179-1183.

3. Coccagna G, Mantovani M, Parchi C, Mironi F, Lugaresi E. Alveolar hypoventilation and hypersomnia in myotonic dystrophy. J Neurol Neurosurg Psychiatry 1975; 38: 977-984.

4. Carroll JE, Zwillich CW, Weil JV. Ventilatory response in myotonic dystrophy. Neurology 1977; 27: 1125-1128.

5. Ono S, Kanda F, Takahashi K, et al. Neuronal loss in the medullary reticular formation in myotonic dystrophy: a clinicopathological study. Neurology 1996; 46: 228-231.

6. Moufarrej NA, Bertorini TE. Respiratory insufficiency in adulttype acid maltase deficiency. South Med J 1993; 86: 560-567.

7. Keunen RW, Lambregts PC, Op de Coul AA, Joosten, EM Respiratory failure as initial symptom of acid maltase deficiency. J Neurol Neurosurg Psychiatry 1984; 47: 549-552.

8. Rosenow EC, Engel AG. Acid maltase deficiency in adults presenting as respiratory failure. Am J Med 1978; 64: 485-491.

9. Di Mauro S, Stern LZ, Mehler M, Nagle RB, Payne C. Adult onset acid maltase deficiency: a post-mortem study. Muscle Nerve 1978; 1: 27-36.

10. Engel AG, Gomez MR, Seybold ME, Lambert EH. The spectrum and diagnosis of acid maltase deficiency. Neurology 1973; 23: 95-106.

11. Angelini C, Engel AG. Comparative study of acid maltase deficiency. Biochemical differences between infantile, childhood, and adult types. Arch Neurol 1972; 26: 344-349.

12. Karpati G, Carpenter S, Eisen A, Aube M, DiMauro S. The adult form of acid maltase (alpha-1, 4-glucosidase) deficiency. Ann Neurol 1977; 1: 276-280.

13. Loonen MC, Busch HFM, Koster JF, et al. A family with different clinical forms of acid maltase deficiency (glycogenosis type II) biochemical and genetic studies. Neurology 1981; 31: 12091216.

14. Swash M, Schwartz MS, Apps MCP. Adult onset acid maltase deficiency. Distribution and progression of clinical and pathological abnormality in a family. J Neurol Sci 1985; 68: 61-74.

15. Wijdicks EFM. Neurology of Critical lllness. Davis FA, Philadelphia, 1995.

16. Joutel A, Moulonguet A, Demaugre F, et al. Type II carnitine palmitoyl transferase deficiency complicated by acute respiratory failure. Rev Neurol 1993; 149: 797-799.

17. Barohn RJ, Clanton T, Sahenk Z, Mendell JR. Recurrent respiratory insufficiency and depressed ventilatory drive complicating mitochondrial myopathies. Neurology 1990; 40: 103-106. 
18. Robertson PL, Roloff DW. Chronic respiratory failure in limb-girdle muscular dystrophy: successful long-term therapy with nasal bilevel positive airway pressure. Pediatr Neurol 1994; 10: 328331.

19. Altobellis SS, Roy TM, Joyce BW, Byrd RP 3rd. Respiratory failure and death from HIV-associated myopathy. J Ky Med Assoc 1992; 90: 174-177.

20. Dewberry RG, Schneider BF, Cale WF, Phillips LH 2nd. Sarcoid myopathy presenting with diaphragm weakness. Muscle Nerve 1993; 16: 832-835.

21. Fu ES, Scharf JE, Mangar D, Miller WD. Malignant hyperthermia involving the administration of desflurane. Can J Anaesth 1996; 43: 687-690.

22. DeVere R, Bradley WG. Polymyositis: its presentation, morbidity, and mortality. Brain 1975; 98: 637-666.

23. Howard RS, Wiles CM, Hirsch NP, Spencer GT. Respiratory involvement in primary muscle disorders: assessment and management. Q J Med 1993; 86: 175-189.

24. Gravelyn TR, Brophy N, Siegert C, Peters-Golden M. Hypophosphatemia associated respiratory muscle weakness in a general inpatient population. Am J Med 1988; 84: 870-876.

25. Davis MJ, Cilo M, Plaitakis A, Yahr MD. Trichinosis; severe myopathic involvment with recovery. Neurology 1976; 26: 37-40.

26. Zochodne DW, Ramsay DA, Saly V, Shelley S, Moffatt S. Acute necrotizing myopathy of intensive care: electrophysiological studies. Muscle Nerve 1994; 17: 285-292.

27. Hirano M, Ott BR, Raps EC, et al. Acute quadriplegic myopathy: a complication of treatment with steroids, nondepolarizing blocking agents, or both. Neurology 1992; 42: 2082-2087.

28. Minetti C, Hirano M, Morreale G, et al. Ubiquitin expression in acute steroid myopathy with loss of myosin thick filaments. Muscle Nerve 1996; 19: 94-96.
29. Ramsay DA, Zochodne DW, Robertson DM, Nag S, Ludwin SK. A syndrome of acute severe muscle necrosis in intensive care unit patients. J Neuropathol Exp Neurol 1993; 52: 387-398.

30. Segredo V, Caldwell JE, Matthay MA, et al. Persistent paralysis in critically ill patients after long-term administration of vecuronium. N Engl J Med 1992; 327: 524-528.

31. Danon MJ, Carpenter S. Myopathy with thick filament (myosin) loss following prolonged paralysis with vecuronium during steroid treatment. Muscle Nerve 1991; 14: 1131-1139.

32. Henrich WL, Prophet D, Knochel JP. Rhabdomyolysis associated with Escherichia coli septicemia. South Med J 1980; 73: 936937.

33. Ho KJ, Scully KT. Acute rhabdomyolysis and renal failure in Weil's disease. Ala J Med Sci 1980; 17: 133-137.

34. Johnson WD Jr, Silva IC, Rocha H. Serum creatine phosphokinase in leptospirosis. JAMA 1975; 233: 981-982.

35. Posner MR, Caudill MA, Brass R, Ellis, E. Legionnaire's disease associated with rhabdomyolysis and myoglobinuria. Arch Intern Med 1980; 140: 848-850.

36. Adamski GB, Garin EH, Ballinger WE, Shulman, ST. Generalized nonsuppurative myositis with staphylococcal septicemia. J Pediatr 1980; 96: 694-697.

37. Armstrong JH. Tropical pyomyositis and myoglobinuria. Arch Intern Med 1978; 138: 1145-1146.

38. Lannigan R, Austin TW, Vestrup J. Myositis and rhabdomyolysis due to Staphylococcus aureus septicemia. J Infect Dis 1984; 150: 784.

39. Bolton CF, Young GB, Zochodne DW. Neurological changes during severe sepsis. In: Dobbs GJ, ed. Current Topics in Intensive Care 1. Philadelphia: Saunders WS, 1994; 180-217. 